\title{
Araçá (Psidium cattleianum Sabine): bioactive compounds, antioxidant activity and pancreatic lipase inhibition
}

\author{
Elisa dos Santos Pereira ${ }^{1}$ iD Juliana Rocha Vinholes ${ }^{2}$ iD Taiane Mota Camargo ${ }^{1}$ \\ Chirle de Oliveira Raphaelli ${ }^{*}$ (iD Núbia Marilin Lettnin Ferri ${ }^{2}$ iD Leonardo Nora $^{1}$ iD \\ Márcia Vizzotto ${ }^{2}$ iD
}

${ }^{1}$ Programa de Pós-graduação em Ciência e Tecnologia de Alimentos, Universidade Federal de Pelotas (UFPel), Campus Capão do Leão, s/n, 96010-900, Capão do Leão, RS, Brasil. E-mail: chirleraphaelli@hotmail.com. *Correponding author.

${ }^{2}$ Embrapa Clima Temperado, Pelotas, RS, Brasil.

ABSTRACT: “Araçá" has been reported with different biological activities such as antioxidant, antiproliferative and antimicrobial as well as inhibitors of digestive enzymes. The digestive pancreatic lipase enzyme plays a fundamental role in lipid metabolism, and its inhibition has been studied as a target for obesity treatment. This study quantified the bioactive compounds present in different parts of "araça'" fruit and evaluated their antioxidant activity and lipase inhibition properties. Three samples were analyzed for total anthocyanins, total phenolic content, antioxidant activity and pancreatic lipase inhibition. Anthocyanins were reported only in pulp-peel of red "araçá" sample. Phenolic compounds concentration was higher in pulp-peel than in seeds for all samples. The antioxidant activity followed the same trend. A positive correlation was observed between total phenolic content and both antioxidant activity and lipase inhibition. Lipase inhibition activity was higher for pulp-peel compared to the seeds. Overall, the results showed that "araça" fruit extracts could be beneficial for the treatment of obesity.

Key words: anthocyanins, phenolic compounds, pulp-peel, seed, native fruit.

Araçá (Psidium cattleianum Sabine): compostos bioativos, atividade antioxidante e inibição da lipase pancreática

RESUMO: A fruta araçá tem sido destacada por suas diferentes atividades biológicas como antioxidante, antiproliferativa e antimicrobiana, além de inibidores de enzimas digestivas. A enzima digestiva lipase tem papel fundamental no metabolismo lipídico, e sua inibição tem sido estudada como alvo para o tratamento da obesidade. Este estudo teve como objetivo quantificar os compostos bioativos presentes em diferentes partes do fruto do araçá e avaliar sua atividade antioxidante e propriedades de inibição da lipase. Três amostras foram analisadas quanto a antocianinas totais, compostos fenólicos totais, atividade antioxidante e inibição da lipase pancreática. Antocianinas foram encontradas apenas na polpa-casca da amostra de araçá vermelho. A concentração de compostos fenólicos foi maior na polpa-casca do que nas sementes para todas as amostras. A atividade antioxidante seguiu a mesma tendência. Os compostos fenólicos totais, a atividade antioxidante e a inibição da lipase apresentaram uma correlação positiva. A atividade de inibição da lipase foi ligeiramente superior para a polpa-casca em comparação com as sementes. No geral, os resultados revelaram que os extratos da fruta do araçá podem ser benéficos para o tratamento da obesidade.

Palavras-chave: antocianinas, compostos fenólicos, polpa-casca, semente, fruta nativa.

\section{INTRODUCTION}

"Araçá" (Psidium cattleianum Sabine) is a native Brazilian fruit from the Myrtaceae family originating in the south of Brazil, that is harvested between January and May (PEREIRA et al., 2018). "Araçá" peel colour can be yellow or red, and its pulp is mucilaginous, aromatic, and contains many seeds (MEREGALLI et al., 2020). Psidium cattleianum is known by different names such as "araçá", "araçá-rosa”, "araçá-de-comer", "araçá-dapraia" and "araçá-coroa" (PEREIRA et al., 2018) and is consumed in natura, and preserved as jams, jellies, and juices (REISIG et al., 2016). Due to its high content of vitamin $\mathrm{C}$ and bioactive compounds with an array of properties (e.g. antioxidant, 
anticarcinogenic, analgesic, and antimicrobial), it also merits exploration by the pharmaceutical industry (ALMEIDA LOPES, DE; SILVA, E. De O., 2018; MEDINA et al., 2011; PEREIRA et al., 2018). In vivo research has shown that "araca" can improve blood glucose levels, reduce low-density lipoprotein (LDL), and total blood cholesterol levels, and decrease fat deposition in the liver when administered in the diet of rats (DALLA-NORA et al., 2014).

The biological activities reported for "araçá" are related to phenolic compounds and carotenoids reported to be present in "araçá" fruits (ALMEIDA LOPES et al., 2018; CORRÊA et al., 2011). Consumption of foods rich in phenolic compounds is associated with reduced risk of health disorders due to their neutralization of excess free radicals and reactive oxygen species (BELISÁRIO et al., 2020; SHAHIDI \& AMBIGAIPALAN, 2015). Phenolic compounds can also inhibit specific digestive enzymes (WU et al., 2020). Pancreatic lipase acts in the breakdown of fats, including triglycerides and phospholipids, playing an important role in lipid metabolism. Thus, inhibitors of this enzyme represent a potential therapeutic route for obesity due to their reduction of lipid digestion and absorption at the peripheral level. Considering that $50-70 \%$ of total dietary fat hydrolysis is performed by pancreatic lipase, inhibition of this enzyme is a potential stand alone treatment for obesity (ALIAS et al., 2017). Orlistat, obtained from Streptomyces toxytricini, is currently the only pancreatic lipase inhibitor approved for clinical use (FINER et al., 2000; ZHANG et al., 2018). It can produce side effects including flatulence, oily spots, abdominal cramps, urgency, faecal incontinence, and steatorrhea (CHAPUT \& TREMBLAY, 2007) that reduce patient compliance with treatment regimens. Alternatives are needed, potentially including the use of natural products.

Antioxidant compound content is dependent on the part of the fruit analyzed. Some phenolic compounds are present in greater quantities in the pulp and bark than in the seeds of Momordica cochinchinensis and other exotic fruits from Colombia (CONTRERAS-CALDERÓN et al., 2011; KUBOLA \& SIRIAMORNPUN, 2011). Genetic variability of this fruit should also be considered, because there are variations in alleles within the species, both between different populations of the same species, and within single populations (GRIFFITHS et al., 2000). These factors may influence fruit composition and biological activity. Thus, this study verified the potential of different genotypes, and different parts of "araçá" fruit to inhibit pancreatic lipase activity, and to broadly assess "araca" bioactive compound and antioxidant activity content.

\section{MATERIALS AND METHODS}

\section{Standards and reagents}

Reagents were purchased from various suppliers. Phosphate buffer ( $\mathrm{pH} 7.0$ ), 2,2-diphenyl1-picrylhydrazyl (DPPH') D9132, cyanidin-3$O$-glucoside, Folin-Ciocalteu reagent V0S0427, chlorogenic acid C3878, sodium carbonate, and Lipase kit MAK046 were purchased from SigmaAldrich (St. Louis, MO, EUA). Ethanol, methanol, and hydrochloric acid were purchased from VETEC (Duque de Caxias, RJ, Brazil).

"Araçá" samples
Three samples of "araçá" were obtained from the Active Germplasm Bank of native fruits at Embrapa Clima Temperado $\left(31^{\circ} 40^{\prime} 47^{\prime \prime} \mathrm{S}\right.$, $52^{\circ} 26^{\prime} 24^{\prime} \mathrm{W}, \mathrm{RS}$, Brazil, accession numbers AC 44 and AC 87 (red genotype), and Bicudo cultivar (yellow genotype)). Several fruits from three plants of each cultivar or accession (a new plant variant obtained via tissue culture, chemical treatment, or any classical breeding practice, not yet characterized, but assigned an accession number) were harvested when ripe between March and April of 2016. Samples were transported to the laboratory in boxes at $25^{\circ} \mathrm{C}$, within $30 \mathrm{~min}$. Pulp-peel were manually separated from the seeds, and both were frozen at $-20^{\circ} \mathrm{C}$. Samples were lyophilized and ground (particles diameter $<5 \mu \mathrm{m}$ ) under liquid nitrogen using a ball mill, and stored at $-80^{\circ} \mathrm{C}$ until analyzed.

\section{Total anthocyanin content}

Total anthocyanin content was measured as described (FULEKI \& FRANCIS, 1968). Briefly, $250 \mathrm{mg}$ of freeze-dried "araçá" sample was mixed with $10 \mathrm{~mL}$ of extraction solvent [85:15 ethanol (95\%): hydrochloric acid (1.5 M)] and stirred for 5 min. Samples at a concentration of $25 \mathrm{mg} / \mathrm{mL}$ were filtered (paper filter Whatman $\mathrm{n}^{\circ} 4$ ), and absorbance was measured at $535 \mathrm{~nm}$. Results were expressed as equivalents of cyanidin-3-O-glucoside, based on a cyanidin-3-O-glucoside $(-0-0.4 \mathrm{mg} / \mathrm{mL})$ standard curve $\left(\mathrm{y}=0,0451 \mathrm{x}+0,0006 r^{2}=0,9964\right)$.

\section{Total phenolic content}

Total phenolic content was measured using the Folin-Ciocalteu method adapted from SWAIN \& HILLIS (1959). Briefly, $250 \mathrm{mg}$ samples 
of each freeze-dried powder was stirred for $5 \mathrm{~min}$ in $10 \mathrm{~mL}$ methanol $(1: 40 \mathrm{w} / \mathrm{v})$ and filtered (paper filter Whatman $\left.n^{\circ} 4\right)$. A $250 \mu \mathrm{L}$ aliquot of each sample $(25$ $\mathrm{mg} / \mathrm{mL}$ ) was combined with $4 \mathrm{~mL}$ of water and 250 $\mu \mathrm{L}$ of Folin-Ciocalteu reagent $(0.25 \mathrm{~N})$. After a $3 \mathrm{~min}$ incubation, $500 \mu \mathrm{L}$ of $\mathrm{Na}_{2} \mathrm{CO}_{3}(1 \mathrm{~N})$ was added, and mixtures were incubated for $2 \mathrm{~h}$ at room temperature. Absorbance was measured at $725 \mathrm{~nm}$, and results were expressed as chlorogenic acid equivalents (CAE g/100 $\mathrm{g}$ fresh weight) using a chlorogenic acid $(-0-0.5 \mathrm{mg} /$ $\mathrm{mL})$ standard curve $\left(\mathrm{y}=0,5825 \mathrm{x}-0,0101 r^{2}=0,9907\right)$.

\section{Antioxidant activity using $D P P H^{\circ}$}

Antioxidant activity was measured using a method described by THAIPONG et al. (2006). Lyophilized "araçá" samples $(250 \mathrm{mg})$ were stirred for $5 \mathrm{~min}$ in $10 \mathrm{~mL}$ methanol $(1: 40 \mathrm{w} / \mathrm{v})$ and filtered (paper filter Whatman $\mathrm{n}^{\circ} 4$ ). A $200 \mu \mathrm{L}$ aliquot of each sample $(25 \mathrm{mg} / \mathrm{mL})$ was mixed with $2.8 \mathrm{~mL}$ of $0.10 \mathrm{mM}$ methanolic $\mathrm{DPPH}^{\bullet}$ solution (THAIPONG et al., 2006). Reactions were incubated in the dark at room temperature for $24 \mathrm{~h}$, and absorbance was measured at $515 \mathrm{~nm}$. Results were expressed as Trolox equivalents (Trolox equivalents $\mu \mathrm{g} / \mathrm{g}$ of dry weight) using a Trolox (0-0.5 mg/mL) standard curve $\left(\mathrm{y}=235.89 \mathrm{x}-6.2846, r^{2}=0.9916\right)$.

\section{Nitric oxide radical inhibition}

Nitric oxide radical scavenging activity was measured using a previously described method (VINHOLES et al., 2017). Lyophilized "araçá" samples $(62.5 \mathrm{mg})$ were stirred for $5 \mathrm{~min}$ in $10 \mathrm{~mL}$ of $50 \%$ ethanol $(1: 40, \mathrm{w} / \mathrm{v})$. Samples were filtered (paper filter, Whatman $\mathrm{n}^{\circ} 4$ ) and stored at $-20^{\circ} \mathrm{C}$ until analyzed. A $50 \mu \mathrm{L}$ aliquot of each extract $(6.25 \mathrm{mg} /$ $\mathrm{mL}$ ) or the $50 \%$ ethanol control were mixed with $50 \mu \mathrm{L}$ of $20 \mathrm{mM}$ sodium nitroprusside, and incubated for 60 min at room temperature under light. Fifty microliters of Griess reagent $(0.1 \%$ naphthylethylenediamine dihydrochloride and $1 \%$ sulphanilamide in $2 \%$ phosphoric acid) was then added, and mixtures were incubated at room temperature in the dark for $10 \mathrm{~min}$. Absorbance at $562 \mathrm{~nm}$ was measured, and results were expressed as percent inhibition (I\%) using equation 1 : $I \%=\frac{\text { Acontrol }- \text { Asample }}{\text { Acontrol }} \times 100$

where $\mathrm{A}_{\text {control }}$ is absorbance of the control reaction (all reagents, except the extract), and $\mathrm{A}_{\text {sample }}$ is absorbance of the dissolved "araca" extract.

\section{Pancreatic lipase inhibition}

Lipase inhibition was measured using the procedure described in the Lipase Activity Assay
Kit (MAK046; Sigma-Aldrich). Lyophilized "araçá" samples $(250 \mathrm{mg})$ were stirred for $5 \mathrm{~min}$ in $10 \mathrm{~mL}$ of ethanol $(50 \%)(1: 40, \mathrm{w} / \mathrm{v})$. Samples were filtered (paper filter, Whatman $\mathrm{n}^{\circ} 4$ ) and stored at $-20^{\circ} \mathrm{C}$ until analyzed. Extract samples $(2.5 \mathrm{mg} / \mathrm{mL})$ were added separately to the lipase mixture. Absorbance was recorded in a microplate reader and compared with that of the lipase mixture without extract (control). Absorbance was measured at $570 \mathrm{~nm}$ at $\mathrm{T} 1$ to read $\mathrm{A} 1$ and at $\mathrm{T} 2$ after incubating the reaction at $37^{\circ} \mathrm{C}$ for 40 min. Change in $\mathrm{A}_{570}$ Between T1 and T2 (A2-A1) represents glycerol oxidation. Lipase activity was calculated using equation 2 ,

Lipase activity $\frac{\mathrm{mU}}{\mathrm{mL}}=\frac{B-\text { dilution factor }}{(T 2-T 1) \times \mathrm{V}}$

in which $\mathrm{B}$ is the glycerol concentration in the standard curve (nmol), $\mathrm{V}$ is the pre-treated sample volume $(\mathrm{mL})$ added to each reaction well, $\mathrm{T} 1$ is the time of the initial reading (A1) (min), and $\mathrm{T} 2$ is the time of the second reading (A2) (min). One unit is defined as the amount of lipase needed to hydrolyse triglycerides at a rate yielding $1.0 \mu \mathrm{mol}$ of glycerol per min at $37^{\circ} \mathrm{C}$. Orlistat (Xenical) at a final concentration of $0.24 \mathrm{mg} / \mathrm{mL}$ was used as a positive control for lipase inhibition, based on a value reported in the literature (CHATER et al., 2016). Percent inhibition of lipase extracts was calculated using equation 3 :

$\%$ Inhibition of lipase $=\frac{\text { lipase activity of control }- \text { lipase activity of sample }}{\text { lipase activity of control }} \times 100$

\section{Statistical analysis}

Analyses were performed in triplicate $(\mathrm{n}=3)$ and results (means \pm standard deviation) were calculated using Microsoft Excel. Results for total anthocyanin content, total phenolic content, antioxidant activity, nitric oxide radical inhibition, and lipase inhibition were submitted to analysis of variance. Means were compared between "araçá" genotypes and parts (pulp-peel vs. seeds) for each assay by Tukey test at a 0.05 confidence level using WinStat 2.11.

\section{RESULTS AND DISCUSSION}

The increased prevalence of overweight people in the world's population reinforces interest in identification of foods with high levels of bioactive compounds (INOUE et al., 2018). Consumption of foods high in phenolic compounds has been associated with reduced risk for development of chronic diseases such as cancer, cardiovascular 
diseases, obesity, and atherosclerosis (SHAHIDI \& AMBIGAIPALAN, 2015).

All "araçá" samples afforded considerable amounts of phenolic compounds. Anthocyanins were detected only in the pulp-peel of red genotype "araçá", with concentrations of 42.2 and 43.7 $\mathrm{mg} / 100 \mathrm{~g}$ dried sample (Table 1). This was expected, because these compounds are responsible for the red color of AC 44 and AC 87 samples (VEBERIC et al., 2015). Total phenolic content was similar among all genotypes. However, higher content was observed in pulp-peel fractions than in seeds among all genotypes. Values for this parameter varied from 1418.5 to $1533.4 \mathrm{mg} / 100 \mathrm{~g}$ in seeds, and 1933.3 to $2088.5 \mathrm{mg} / 100 \mathrm{~g}$ in pulp-peel (Table 1). These values are higher than those reported by Denardin et al. (2015) $(660,19 \mathrm{mg} / 100 \mathrm{~g})$. By contrast, CHAVES et al. (2018) reported higher concentrations of phenolic compounds in the red genotype $(719,00 \mathrm{mg} / 100 \mathrm{~g})$ compared to the yellow genotype $(382 \mathrm{mg} / 100 \mathrm{~g})$. Phenolic compounds including catechin and ellagic acid were found in high quantities in pulp-peel extracts of AC44, AC87, and Bicudo, while catechin, ellagic acid, and quercetin were the major compounds in seed extracts (PEREIRA et al., 2020).

All "araçá" samples showed scavenging capacity towards DPPH radical. However, for all samples, the pulp-peel extracts were more active than the seed extracts. The yellow genotype (Bicudo) and AC 87 showed the highest activity (Table 1). Values for antioxidant activity varied from 154.9 to 330.3 $\mu \mathrm{g} / \mathrm{g}$ in seeds, and 1097.7 to $1277.0 \mu \mathrm{g} / \mathrm{g}$ in pulppeel. The antioxidant activity assay using DPPH• stable radical is widely used to assess native fruits (MEDINA et al., 2011; VINHOLES et al., 2017). "Araçá" showed higher antioxidant activity than "uvaia" or "guabiroba", with a value of $389.7 \mu \mathrm{g} / \mathrm{g}$, similar to results observed for seeds in the present study (PEREIRA et al., 2012).

The antioxidant activity in the pulp-peel of "camu-camu" and "araçá-boi" fruits, both from the Myrtaceae family, yielded values of $34.79 \mu \mathrm{g}$ trolox $/ \mathrm{g}$ and $6048.26 \mu \mathrm{g}$ trolox/g dried fruit (NEVES et al., 2015). The peels of both samples showed higher antioxidant activities than their pulps. In one other study of fruits from the Myrtaceae family, antioxidant activity values were between $3455.85 \mu \mathrm{g}$ trolox/g and $16997.37 \mu \mathrm{g}$ trolox/g of fruit (BARROS et al., 2017).

Nitric oxide radical (NO•) inhibition was also higher in pulp-peel extracts, but did not differ significantly among genotypes, with inhibition ranging from $72.1 \%$ to $73.0 \%$. Inhibition by seed extracts varied from $18.3 \%$ to $50.0 \%$, with the yellow genotype (Bicudo) being the most active

Table 1 - Total anthocyanins content and total phenolic content, antioxidant activity and inhibition of pancreatic lipase of differents "araçá" genotypes ${ }^{[a]}$.

\begin{tabular}{|c|c|c|c|c|c|}
\hline Sample & $\begin{array}{c}\text { Total anthocyanins } \\
\text { content }^{[\mathrm{b}]}\end{array}$ & $\begin{array}{l}\text { Total phenolic } \\
\text { content }^{[\mathrm{c}]}\end{array}$ & $\begin{array}{l}\text { Antioxidant activity } \\
\mathrm{DPPH}^{\cdot}[\mathrm{d}]\end{array}$ & $\begin{array}{c}\mathrm{NO}^{\circ} \text { radical } \\
\text { inhibition }(\%)\end{array}$ & $\begin{array}{c}\text { Pancreatic lipase } \\
\text { inhibition (\%) }\end{array}$ \\
\hline Pulp-peel & - & $1954.2 \pm 21.8 \mathrm{a}$ & $1277.0 \pm 55.5 \mathrm{a}$ & $72.9 \pm 6.0 \mathrm{a}$ & $54.2 \pm 7.0 \mathrm{a}$ \\
\hline Seed & - & $1418.5 \pm 41.4 b$ & $327.1 \pm 26.2 \mathrm{c}$ & $50.0 \pm 10.2 \mathrm{~b}$ & $34.9 \pm 11.4 b$ \\
\hline Pulp-peel & $42.2 \pm 4.3 \mathrm{a}$ & $1933.3 \pm 44.6 \mathrm{a}$ & $1097.7 \pm 23.0 \mathrm{~b}$ & $73.0 \pm 5.1 \mathrm{a}$ & $57.9 \pm 2.05 \mathrm{a}$ \\
\hline Seed & - & $1488.9 \pm 20.7 b$ & $330.3 \pm 11.0 \mathrm{c}$ & $18.3 \pm 7.4 \mathrm{c}$ & $42.5 \pm 7.6 \mathrm{~b}$ \\
\hline Pulp-peel & $43.7 \pm 5.0 \mathrm{a}$ & $2088.5 \pm 22.0 \mathrm{a}$ & $1260.4 \pm 38.7 \mathrm{a}$ & $72.1 \pm 5.8 \mathrm{a}$ & $49.4 \pm 11.0 \mathrm{ab}$ \\
\hline Seed & - & $1533.4 \pm 28.4 b$ & $154.9 \pm 13.1 \mathrm{~d}$ & $30.2 \pm 4.9 \mathrm{~d}$ & $44.0 \pm 0.1 \mathrm{~b}$ \\
\hline
\end{tabular}

\footnotetext{
${ }^{[a]}$ Mean values $(n=3)$ in a column followed by the same letter are not significantly different from each other $(<0.05$ ANOVA followed by Tukey test).

${ }^{[\mathrm{b}]}$ Total anthocyanins expressed as mg of cyanidin-3-O-glucoside equivalents/100 g dry basis. ${ }^{[\mathrm{c}]}$ Total phenolic content expressed as mg of chlorogenic acid equivalent/100 g dry basis. ${ }^{[\mathrm{d}]}$ Antioxidant activity expressed as $\mu \mathrm{g}$ of Trolox equivalents $/ \mathrm{g}$ dry basis.
} 
(Table 1). The NO• radical is a signaling molecule produced in the body that is responsible for different physiological and pathological processes. In pathological conditions, this radical is produced in excess, causing damage such as DNA fragmentation, cell damage, and neuronal cell death. In addition, $\mathrm{NO} \bullet$ is neurotoxic, mediating pathological processes such as cerebral ischemia, epilepsy, Alzheimer's disease, and Parkinson's disease. Thus, its inhibition is of great importance (RADÜNZ et al., 2020).

Nitric oxide radical inhibition apparently correlates with levels of bioactive compounds present in "araçá" fruit (VINHOLES et al., 2017; VINHOLES et al., (2018). It has been reported that even after gastrointestinal digestion, one-third of the phenolic compounds present in "araçá" extracts remains, suggesting strong prospects for maintaining its antioxidant activity.

The phenolic compounds ellagic acid, gallic acid, epicatechin, catechin, and quercetin, reported as "araçá" constituents (MEDINA et al., 2011; PEREIRA et al., 2020), are capable of maintaining endogenous anti-inflammatory, anticarcinogenic, antimicrobial, and antioxidant defense systems.

All "araçá" samples were able to inhibit pancreatic lipase, with greater potency in pulp-peel extracts than in seed extracts (except in AC 87), with percent inhibition above 54\% (Table 1). Moreover, all samples, except for Bicudo seed extract, showed inhibitory values significantly higher than that of the positive control orlistat $(31.2 \pm 3.3 \%)$. AC 44 , with high enzymatic inhibition, has cyanidin3-O-glucoside and catechin as major constituents (PEREIRA et al., 2020). Bicudo and AC 87 contain high catechin concentrations (PEREIRA et al., 2020).

Myrtaceae fruits showed promising lipase inhibition results (BATUBARA et al., 2009) and some phenolic compounds present in "araçá" are relevant to inhibition of specific enzymes such as the glutathione oxidases (VALKO et al., 2007), and a-glucosidase (VINHOLES, J. et al., 2017).

To our knowledge, this is the first report of "araçá" (Psidium cattleianum) ability to inhibit this enzyme. Polyphenols are the main class of pancreatic lipase inhibitors (BUCHHOLZ \& MELZIG, 2015) due to chemical characteristics that facilitate bond formation between these compounds and the enzyme (BUCHHOLZ \& MELZIG, 2015). Compounds such as myricetin, kaempferol glucosides, catechin/ epicatechin, and procyanidins are associated with pancreatic lipase inhibition (BUCHHOLZ \& MELZIG, 2015; CAMARGO et al., 2017; GENDARAM et al., 2017; YOSHIKAWA et al., 2009; ZHANG, B. et al., 2015). The antihyperlipidemic action of catechin is due to its inhibition of key enzymes involved in lipid biosynthesis, and its ability to reduce intestinal absorption of lipids (ANANDH BABU; LIU, 2008). Other studies have reported ellagic acid, quercetin (MARTINEZ-GONZALEZ et al., 2017), and anthocyanins to be lipase inhibitors (YOU et al., 2011). Different biological properties such as thermogenic activity, fat oxidation ability, appetite control, obesity-related hormone level regulation, and inhibition of digestive enzymes involved in the absorption of carbohydrates and lipids are ascribed to the phenolic compounds chlorogenic acid, the catechins, and quercetin, present in "araçá" (SIMÃO et al., 2017).

Correlation analysis showed that the antioxidant activity, nitric oxide radical inhibition, and lipase inhibition positively correlated with total phenolic content (Table 2). Different pharmacological properties have been ascribed to "araçá" that are associated with its chemical composition. In fact, the Psidium genus has been described as having antioxidant, antidiabetic, anticancer, antimicrobial, anti-inflammatory, and anti-aging activities, among others (PEREIRA et al., 2018). These properties

Table 2 - Correlation between the total phenolic content (TPC), antioxidant activity (DPPH'), nitric oxide radical inhibition and pancreatic lipase inhibition of "araçá" genotypes.

$\mathrm{TPC}$

$\mathrm{DPPH}^{\cdot} \quad 0.959$


showed this fruit's potential applications in the food and pharmaceutical industries.

Since few drug options exist for treating obesity, and orlistat has side effects, research into, and development of natural products with pancreatic lipase inhibition are an inspiring avenue of research in pursuit of new therapies. Natural products containing phenolic compounds have already shown efficient inhibition of pancreatic lipase. More detailed studies are still needed. This research may provide some guidance in the development of other studies, given the promise of pancreatic lipase inhibitors for treatment of obesity and related disorders.

\section{CONCLUSION}

The present study described bioactive compounds (total anthocyanins and total phenolic content), antioxidant activity, nitric oxide radical neutralization, and pancreatic lipase inhibition of three "araçá" samples. Anthocyanins were present only in red "araçá" genotypes. Total phenolic content was similar among genotypes, but was tissue type dependent within the fruit. Pulp-peel extracts showed higher phenolic content and antioxidant and antiradical activities. This study provided, to our knowledge, the first assessment of pancreatic lipase inhibition by this species. All extracts inhibited lipase more efficiently than orlistat. Thus, "araçá" may provide considerable amounts of phenolic compounds with antioxidant activity and lipase inhibitory properties. Research is being conducted to develop a functional food containing "araçá" extracts, which preserves its biological properties, to aid in controlling and combating obesity.

\section{ACKNOWLEDGEMENTS}

The authors would like to acknowledge Fundação Coordenação Aperfeiçoamento de Pessoal de Nível Superior (CAPES) for providing the financial support for the completion of the present work.

\section{DECLARATION OF CONFLICT OF INTERESTS}

The authors declare no conflict of interest. The founding sponsors had no role in the design of the study; in the collection, analyses, or interpretation of data; in the writing of the manuscript, and in the decision to publish the results.

\section{AUTHORS' CONTRIBUTIONS}

All authors contributed equally for the conception and writing of the manuscript. All authors critically revised the manuscript and approved of the final version.

\section{REFERENCES}

ALIAS, N. et al. Anti-obesity potential of selected tropical plants via pancreatic lipase inhibition. Advances in Obesity, Weight Management \& Control, v. 6, n. 4, 2017. Available from: $<$ https:// medcraveonline.com/AOWMC/AOWMC-06-00163.pdf>. Accessed: March. 22, 2021. doi: 10.15406/aowmc.2017.06.00163.

ALMEIDA LOPES, M. M. et al. Araçá-Psidium cattleyanum Sabine. Exotic Fruits, Elsevier, 2018. 466p.

ANANDH BABU, P.; LIU, D. Green tea catechins and cardiovascular health: An update. Current Medicinal Chemistry, v. 15 , n. 18 , p. $1840-1850,2008$. Available from: <https://www. ncbi.nlm.nih.gov/pmc/articles/PMC2748751/>. Accessed: Aug. 02, 2020. doi: 10.2174 / 092986708785132979.

BARROS, R. G. C. et al. Evaluation of bioactive compounds potential and antioxidant activity in some Brazilian exotic fruit residues. Food Research International, v. 102, p. 84-92, 2017. Available from: <https://www.sciencedirect.com/science/article/ abs/pii/S0963996917306671>. Accessed: Oct. 12, 2020. doi: 10.1016/j.foodres.2017.09.082.

BATUBARA, I.; et al. Screening antiacne potency of Indonesian medicinal plants: Antibacterial, lipase inhibition, and antioxidant activities. Journal of Wood Science, v. 55, n. 3, p. 230-235, 2009. Available from: <https://jwoodscience.springeropen.com/ articles/10.1007/s10086-008-1021-1>. Accessed: Aug. 21, 2020. doi: 10.1007/s10086-008-1021-1.

BELISÁRIO, C. M. et al. Carotenoids, sugars, ascorbic acid, total phenolics, and antioxidant activity of murici from Brazilian Cerrado during refrigerated storage. Ciência Rural, v. 50, n. 4, p. 1-8, 2020. Available from: <https://www.scielo.br/scielo. php? script $=$ sci_arttext $\&$ pid $=$ S0103-84782020000400751>. Accessed: Aug. 05, 2020. doi: 10.1590/0103-8478cr20180620.

BUCHHOLZ, T.; MELZIG, M. F. Polyphenolic compounds as pancreatic lipase inhibitors. Planta Medica, v. 81, n. 10, p. 771-783, 2015. Available from: $<$ https://pubmed.ncbi.nlm.nih.gov/26132857/>. Accessed: Aug. 22, 2020. doi: 10.1055 / s-0035-1546173.

CAMARGO, A. C. DE; et al. Phenolic profile of peanut byproducts: Antioxidant potential and inhibition of alpha-glucosidase and lipase activities. Journal of the American Oil Chemists' Society, v. 94, n. 7, p. 959-971, 2017. Available from: <https:// link.springer.com/article/10.1007/s11746-017-2996-9>. Accessed: Aug. 15, 2020. doi: 10.1007/s11746-017-2996-9.

CHAPUT, J.; TREMBLAY, A. Currently available drugs for the treatment of obesity: Sibutramine and Orlistat. Mini-Reviews in Medicinal Chemistry, n. 418, p. 3-10, 2007. Available from: $<$ https://pubmed.ncbi.nlm.nih.gov/17266632/\#: :text=The\%20 currently $\% 20$ available $\% 20$ drugs $\% 20$ for, at $\% 201$ east $\% 20$ 1\%2D2\%20years $>$. Accessed: Aug. 01, 2020. doi: $10.2174 / 138955707779317849$.

CHATER, P. I. et al. Inhibitory activity of extracts of Hebridean brown seaweeds on lipase activity. Journal of Applied Phycology, v. 28 , n. 2, p. 1303-1313, 2016. Available from: < https://link. springer.com/content/pdf/10.1007/s10811-015-0619-0.pdf>. Accessed: Aug. 06, 2020. doi: I 10.1007/s10811-015-0619-0.

CHAVES, V. C. et al. Berries grown in brazil: anthocyanins profiles and biological properties. Food Research International, v. 98, n. 
11, p. 4331-4338, 2018. Available from: <https://pubmed.ncbi. nlm.nih.gov/29430645/>. Accessed: July. 30, 2020. doi: 10.1002 / jsfa.8959

CONTRERAS-CALDERÓN, J. et al. Antioxidant capacity, phenolic content and vitamin C in pulp, peel and seed from 24 exotic fruits from Colombia. Food Research International, v. 44 , n. 7 , p. $2047-2053$, 2011. Available from: <https://www. sciencedirect.com/science/article/abs/pii/S0963996910004357>. Accessed: Aug. 21, 2020. doi: 10.1016/j.foodres.2010.11.003.

CORRÊA, L. C. et al. Antioxidant content in guava (Psidium guajava) and araçá (Psidium spp.) germplasm from different Brazilian regions. Plant Genetic Resources, v. 9, n. 3, p. 384-391, 2011. Available from: <https://www. cambridge.org/core/journals/plant-genetic-resources/article/ abs/antioxidant-content-in-guava-psidium-guajava-andaraca-psidium-spp-germplasm-from-different-brazilianregions/88598D94E8A1E1FA99EC2DBF33521713>. Accessed: Aug. 18, 2020. doi: 10.1017/S1479262111000025.

DALLA-NORA, C. et al. Protective effect of guabiju (Myrcianthes pungens $(\mathrm{O}$. Berg) D. Legrand) and red guava (Psidium cattleyanum Sabine) against cisplatin-induced hypercholesterolemia in rats. Brazilian Journal of Pharmaceutical Sciences, v. 50, n. 3, p. 483-492, 2014. Available from: <https://www.scielo.br/scielo. php?script $=$ sci_arttext\&pid $=\mathrm{S} 1984-82502014000300483>$. Accessed: July. 25,2020 . doi: 10.1590/S1984-82502014000300006.

DENARDIN, C. C. et al. Antioxidant capacity and bioactive compounds of four Brazilian native fruits. Journal of Food and Drug Analysis, v. 23, n. 3, p. 387-398, 2015. Available from: $\quad<$ https://www.sciencedirect.com/science/article/pii/ S1021949815000344>. Accessed: July. 25, 2020. doi: 10.1016/j. jfda.2015.01.006.

FINER, N. et al. One-year treatment of obesity: A randomized, double-blind, placebo-controlled, multicentre study of orlistat, a gastrointestinal lipase inhibitor. International Journal of Obesity, v. 24 , n. 3, p. 306-313, 2000. Available from: <https:// pubmed.ncbi.nlm.nih.gov/10757623/>. Accessed: July. 31, 2020. doi: 10.1038 / sj.ijo.0801128

FULEKI, T.; FRANCIS, F. J. Quantitative methods for analysis. Journal of Food Science, v. 33, p. 72-77, 1968. Available from $<$ https://onlinelibrary.wiley.com/doi/10.1111/j.1365-2621.1968 tb00887.x>. Accessed: march 22, 2021. doi: 10.1111/j.13652621.1968.tb00887.x.

GENDARAM, O. et al. Pancreatic lipase inhibitory and antioxidative constituents from the aerial parts of Paeonia lactiflora Pall. (Ranunculaceae). Phytochemistry Letters, v. 21, n. July, p. 240-246, 2017. Available from: <https://www.sciencedirect.com/ science/article/abs/pii/S1874390016303378>. Accessed: March 22, 2020. doi: 10.1016/j.phytol.2017.07.009.

GRIFFITHS, A.; MILLER, J.; SUZUKI, D. An introduction to Genetic Analysis. 7. ed. New York: Elsevier, 2000. 860 p.

INOUE, Y. et al. Epidemiology of obesity in adults: Latest trends. Current obesity reports, v. 7, n. 4, p. 276-288, 2018. Available from: <https://pubmed.ncbi.nlm.nih.gov/30155850/>. Accessed: March. 11, 2020. doi: 10.1007 / s13679-018-0317-8.

KUBOLA, J.; SIRIAMORNPUN, S. Phytochemicals and antioxidant activity of different fruit fractions (peel, pulp, aril and seed) of Thai gac (Momordica cochinchinensis Spreng). Food Chemistry, v. 127, n. 3, p. 1138-1145, 2011. Available from: <https:// www.sciencedirect.com/science/article/abs/pii/S0308814611002226>. Accessed: Oct. 18, 2020. doi: 10.1016/j.foodchem.2011.01.115.

MARTINEZ-GONZALEZ, A. I. et al. In vitro inhibition of pancreatic lipase by polyphenols: A kinetic, Fluorescence spectroscopy and molecular docking study. Food Technology and Biotechnology, v. 55, n. 4, p. 519-530, 2017. Available from: $<$ https://www.ncbi.nlm.nih.gov/pmc/articles/PMC5848196/>. Accessed: Aug. 29, 2020. doi: 10.17113 / ftb.55.04.17.5138.

MEDINA, A. L. et al. Araçá (Psidium cattleianum Sabine) fruit extracts with antioxidant and antimicrobial activities and antiproliferative effect on human cancer cells. Food Chemistry, v. 128 , n. 4 , p. $916-922,2011$. Available from: <https://www. sciencedirect.com/science/article/pii/S030881461100536X>. Accessed: March. 22, 2020. doi: 10.1016/j.foodchem.2011.03.119.

MEREGALLI, M. M. et al. Conventional and ultrasound-assisted methods for extraction of bioactive compounds from red araçá peel (Psidium cattleianum Sabine). Arabian Journal of Chemistry, v. 13 , n. 6 , p. $5800-5809,2020$. Available from: <https://www. sciencedirect.com/science/article/pii/S1878535220301234>. Accessed: March. 20, 2020. doi: 10.1016/j.arabjc.2020.04.017.

NEVES, L. C. et al. Post-harvest nutraceutical behaviour during ripening and senescence of 8 highly perishable fruit species from the Northern Brazilian Amazon region. Food Chemistry, v. 174, p. 188-196, 2015. Available from: <https://www.sciencedirect. com/science/article/abs/pii/S0308814614016756?via\%3Dihub>. Accessed: Aug. 28, 2020. doi: 10.1016/j.foodchem.2014.10.111.

PEREIRA, E. Dos S. et al. Psidium cattleianum fruits: A review on its composition and bioactivity. Food Chemistry, v. 258, p. 95-103, 2018. Available from: <https://www.sciencedirect.com/ science/article/abs/pii/S0308814618304394>. Accessed: March. 05, 2021. doi: 10.1016/j.foodchem.2018.03.024.

PEREIRA, E. Dos S. et al. Characterization of araçá fruits (Psidium cattleianum Sabine): Phenolic composition, antioxidant activity and inhibition of $\alpha$-amylase and $\alpha$-glucosidase. Food Bioscience, p. 100665,2020 . Available from: $<$ https://www.sciencedirect.com/ science/article/abs/pii/S2212429219305231>. Accessed: Feb. 11, 2021. doi: $10.1016 /$ j.fbio.2020.100665.

PEREIRA, M. C. et al. Characterization and antioxidant potential of Brazilian fruits from the Myrtaceae family. Journal of Agricultural and Food Chemistry, v. 60, n. 12, p. 30613067, 2012. Available from: <https://pubs.acs.org/doi/10.1021/ jf205263f $>$. Accessed: Jan. 05, 2021. doi: 10.1021 / jf205263f.

RADÜNZ, M. et al. Antimicrobial potential of spray drying encapsulated thyme (Thymus vulgaris) essential oil on the conservation of hamburger-like meat products. International Journal of Food Microbiology, v. 330, p. 108696, 2020. Available from: <https://www.sciencedirect.com/science/article/abs/pii/ S0168160520301902>. Accessed: Jan. 20, 2021. doi: 10.1016/j. ijfoodmicro.2020.108696.

REISIG, G. N. et al. Bioactive compounds in conventional and no added sugars red strawberry guava (Psidium cattleianum Sabine) jellies. Revista Brasileira de Fruticultura, v. 38, n. 3, p. 1-7, 2016. Available from: $<$ https://www.scielo.br/scielo.php?script=sci_artte xt\&pid=S0100-29452016000300901>. Accessed: Aug. 19, 2020. doi: 10.1590/0100-29452016062. 
SHAHIDI, F.; AMBIGAIPALAN, P. Phenolics and polyphenolics in foods, beverages and spices: Antioxidant activity and health effects - A review. Journal of Functional Foods, v. 18, p. 820-897, 2015. Available from: <https://www.sciencedirect.com/science/ article/pii/S1756464615003023>. Accessed: Aug. 29, 2020. doi: 10.1016/j.jff.2015.06.018.

SIMÃO, A. A. et al. Aqueous extract of Psidium guajava leaves: Phenolic compounds and inhibitory potential on digestive enzymes. Anais da Academia Brasileira de Ciencias, v. 89, n. 3, p. 2155-2165, 2017. Available from: <https://www.scielo.br/ scielo.php?script $=$ sci_arttext\&pid $=$ S0001-37652017000502155>. Accessed: Feb. 26, 2020. doi: 10.1590/0001-3765201720160067.

SWAIN, T.; HILLIS, W. E. The phenolic constituents of Prunus domestica. I.-The quantitative analysis of phenolic constituents. Journal of the Science of Food and Agriculture, v. 10, n. 2, p. 33, 1959. Available from: <https://onlinelibrary.wiley.com/ doi/10.1002/jsfa.2740100110>. Accessed: July. 18, 2020. doi: 10.1002/jsfa.2740100110.

THAIPONG, K. et al. Comparison of ABTS, DPPH, FRAP, and ORAC assays for estimating antioxidant activity from guava fruit extracts. Journal of Food Composition and Analysis, v. 19, n. 6, p. 669-675, 2006. Available from: <https://www.sciencedirect. com/science/article/abs/pii/S0889157506000081>. Accessed: March. 10, 2020. doi: 10.1016/j.jfca.2006.01.003.

VALKO, M. et al. Free radicals and antioxidants in normal physiological functions and human disease. International Journal of Biochemistry and Cell Biology, v. 39, n. 1, p. 44-84, 2007. Available from: <https://pubmed.ncbi.nlm.nih.gov/16978905/>. Accessed: March. 12, 2021. doi: 10.1016 / j.biocel.2006.07.001.

VEBERIC, R. et al. Anthocyanin composition of different wild and cultivated berry species. LWT - Food Science and Technology, v. 60, n. 1, p. 509-517, 2015. Available from: <http://dx.doi. org/10.1016/j.lwt.2014.08.033>. Accessed: Feb. 15, 2021. doi: 10.1016/j.lwt.2014.08.033.

VINHOLES, J. et al. In vitro assessment of the antihyperglycemic and antioxidant properties of araçá, butiá and pitanga. Food Bioscience, v. 19, p. 92-100, 2017. Available from: <https://www. sciencedirect.com/science/article/abs/pii/S2212429217300019> Accessed: Feb. 15, 2021. doi: 10.1016/j.fbio.2017.06.005.
VINHOLES, J. et al. Effect of in vitro digestion on the functional properties of Psidium cattleianum Sabine (araçá), Butia odorata (Barb. Rodr.), Noblick (butiá) and Eugenia uniflora L. (pitanga) fruit extracts. Food and Function, v. 9, n. 12, p. 6380-6390, 2018. Available from: <https://pubs.rsc.org/en/content/ articlelanding/2018/fo/c8fo01329b\#!divAbstract>. Accessed: Feb. 15, 2021. doi: 10.1039/c8fo01329b.

WU, D.-T. et al. Phenolic compounds, antioxidant activities, and inhibitory effects on digestive enzymes of different cultivars of okra (Abelmoschus esculentus). Molecules, v. 25, n. 6, p. 1276, 2020. Available from: <https://www.mdpi.com/14203049/25/6/1276>. Accessed: March. 12, 2021. doi: 10.3390 / moléculas 25061276 .

YOSHIKAWA, M. et al. Acylated oleanane-type triterpene saponins with acceleration of gastrointestinal transit and inhibitory effect on pancreatic lipase from flower buds of Chinese tea plant (Camellia sinensis). Chemistry and Biodiversity, v. 6, n. 6, p. 903-915, 2009. Available from: <https://onlinelibrary.wiley.com/ doi/abs/10.1002/cbdv.200800153>. Accessed: Feb. 12, 2021. doi: $10.1002 / \mathrm{cbdv} .200800153$

YOU, Q. et al. Inhibitory effects of muscadine anthocyanins on $\alpha$-glucosidase and pancreatic lipase activities. Journal of Agricultural and Food Chemistry, v. 59, n. 17, p. 95069511, 2011. Available from: <https://pubs.acs.org/doi/10.1021/ jf201452v>. Accessed: March. 22, 2021. doi: <https://doi. org/10.1021/jf201452v>.

ZHANG, B. et al. Phenolic profiles of 20 Canadian lentil cultivars and their contribution to antioxidant activity and inhibitory effects on $\alpha$-glucosidase and pancreatic lipase. Food Chemistry, v. 172, p. 862-872, 2015. Available from: <https://www. sciencedirect.com/science/article/abs/pii/S0308814614015301>. Accessed: Jan. 05, 2021. < doi: https://doi.org/10.1016/j. foodchem.2014.09.144>.

ZHANG, C. et al. The free, esterified, and insoluble-bound phenolic profiles of Rhus chinensis Mill. fruits and their pancreatic lipase inhibitory activities with molecular docking analysis. Journal of Functional Foods, v. 40, p. 729-735, 2018. Available from: $\quad<$ https://www.sciencedirect.com/science/article/pii/ S1756464617307429>. Accessed: July. 22, 2021. doi: < https://doi. org/10.1016/j.jff.2017.12.019>. 